\title{
SOIL CARBON AND NITROGEN IN PASTURE SOIL REFORESTED WITH EUCALYPTUS AND GUACHAPELE ${ }^{(1)}$
}

\author{
Fabiano de Carvalho Balieiro ${ }^{(2)}$, Marcos Gervasio Pereira ${ }^{(3)}$, Bruno José \\ Rodrigues Alves $^{(4)}$, Alexander Silva de Resende ${ }^{(4)}$ \& Avílio Antonio Franco ${ }^{(5)}$
}

\begin{abstract}
In spite of the normally low content of organic matter found in sandy soils, it is responsible for almost the totality of cation exchange capacity (CEC), water storage and availability of plant nutrients. It is therefore important to evaluate the impact of alternative forest exploitation on the improvement of soil $\mathrm{C}$ and $\mathrm{N}$ accumulation on these soils. This study compared pure and mixed plantations of Eucalyptus grandis and Pseudosamanea guachapele, a $\mathrm{N}_{2}$-fixing leguminous tree, in relation to their effects on soil $\mathrm{C}$ and $\mathrm{N}$ stocks. The studied Planosol area had formerly been covered by Panicum maximum pasture for at least ten years without any fertilizer addition. To estimate $\mathrm{C}$ and $\mathrm{N}$ contents, the soil was sampled (at depths of $0-2.5 ; 2.5-5.0 ; 5.0-7.5 ; 7.5-10.0 ; 10.0-20.0$ and $20.0-40.0 \mathrm{~cm}$ ), in pure and mixed five-year-old tree plantations, as well as on adjacent pasture. The natural abundance ${ }^{13} \mathrm{C}$ technique was used to estimate the contribution of the soil organic $\mathrm{C}$ originated from the trees in the $\mathbf{0}-\mathbf{1 0} \mathrm{cm}$ soil layer. Soil $\mathrm{C}$ and $\mathrm{N}$ stocks under mixed plantation were 23.83 and $1.74 \mathrm{Mg} \mathrm{ha}^{-1}$, respectively. Under guachapele, eucalyptus and pasture areas C stocks were $14.20,17.19$ and $24.24 \mathrm{Mg} \mathrm{ha}^{-1}$, respectively. For these same treatments, total $\mathrm{N}$ contents were $0.83 ; 0.99$ and $1.71 \mathrm{Mg} \mathrm{ha}^{-1}$, respectively. Up to $40 \%$ of the soil organic $\mathrm{C}$ in the mixed plantation was estimated to be derived from trees, while in pure eucalyptus and guachapele plantations these same estimates were only 19 and $27 \%$, respectively. Our results revealed the benefits of intercropped leguminous trees in eucalyptus plantations on soil $\mathrm{C}$ and $\mathrm{N}$ stocks.
\end{abstract}

Index terms: Mixed plantations, Pseudosamanea guachapele, Eucalyptus grandis; soil organic matter, ${ }^{13} \mathrm{C}$ natural abundance.

(1) Parte da Tese de Doutorado do primeiro autor, apresentada ao Curso de Pós-Graduação em Agronomia, Ciência do Solo, Departamento de Solos, Universidade Federal Rural do Rio de Janeiro - UFRRJ. Realizado com apoio financeiro da FAPERJ. Recebido para publicação em março de 2007 e aprovado em março de 2008.

(2) Pesquisador da Embrapa Solos. Rua Jardim Botâncio 1024, Jardim Botânico, CEP 22460-000 Rio de Janeiro (RJ). E-mail: balieiro@cnps.embrapa.br

(3) Professor Adjunto do DPS/UFRRJ. Universidade Federal Rural do Rio de Janeiro - UFRRJ. BR 465, Km 7, CEP 23890-000 Seropédica (RJ). E-mail: gervasio@ufrrj.br

(4) Pesquisador Embrapa Agrobiologia. BR 465, km 7, Bairro Ecologia, Caixa Postal 74500, CEP 23890-000 Seropédica (RJ). E-mails: bruno@cnpab.embrapa.br; alex@cnps.embrapa.br

(5) Superintendente de Institutos Tecnológicos e de Pesquisa da FINEP. Praia do Flamengo, 200 - $13^{\circ}$ andar, CEP 22210-030, Rio de Janeiro (RJ). Email: afranco@finep.gov.br 


\title{
RESUMO: CARBONO E NITROGÊNIO EM SOLO DE PASTAGEM REFLORESTADA COM EUCALIPTO E GUACHAPELE
}

\begin{abstract}
Apesar de os teores de matéria orgânica serem normalmente baixos em solos arenosos, ela é responsável por quase a totalidade da CTC, armazenamento de água e disponibilidade de nutrientes desses solos. A avaliação de sistemas de exploração florestais alternativos, com vistas em incrementar a acumulação de $C$ e $N$, devem ser incentivados. Este estudo compara plantios puros e mistos de Eucalyptus grandis e Pseudosamanea guachapele, leguminosa fixadora de $\mathrm{N}_{2}$, em relação os estoques de $\mathrm{C}$ e $\mathrm{N}$ do solo. Os plantios foram realizados em áreas anteriormente manejadas com Panicum maximum num Planossolo, que, por pelo menos dez anos, não recebeu qualquer fertilizante. Para estimar o $C$ e o $N$ estocado, foram retiradas amostras das camadas de $0-2,5 ; 2,5-5,0 ; 5,0-7,5 ; 7,5-10,0$; 10,0-20,0 e 20,0-40,0 cm tanto nos plantios puros e mistos, quanto na área de pasto. A técnica da abundância natural do ${ }^{13} \mathrm{C}$ foi utilizada na estimativa do Coriginado das árvores nos $10 \mathrm{~cm}$ superficiais. Os estoques de $C$ e $N$, no plantio misto atingiu valores de 23,83 e 1,74 Mg ha-1, respectivamente. Nos puros, de guachapele e eucalipto, e no pasto os estoques de $C$ estimados foram de 14,20; 17,19 e 24,24 Mg ha-1, respectivamente. Para os mesmos tratamentos, os estoques de $N$ foram estimados em 0,83; 0,99 e 1,71 $\mathrm{Mg} \mathrm{ha}^{-1}$, respectivamente. Mais de $40 \%$ do $C$ do solo sob o plantio misto foram estimados como sendo derivados das árvores, enquanto nos plantios puros de eucalipto e guachapele, a contribuição do $C$ das árvores ficou em 19 e $27 \%$, respectivamente. Esses resultados evidenciam que a presença da leguminosa no plantio consorciado aumenta os estoques de C e $\mathrm{N}$ do solo.
\end{abstract}

Termos de indexação: plantios mistos, Eucalyptus grandis, Pseudosamanea guachapele, matéria orgânica do solo, abundância natural do ${ }^{13} \mathrm{C}$.

\section{INTRODUCTION}

Eucalyptus forests in Brazil cover over 3 million hectares replacing, to some extent, the natural Atlantic Forest and Cerrado vegetation. This land use calls for new management techniques that would lessen impacts on biodiversity and processes of soil fertility exhaustion (Novais \& Barros, 1997; Paschoal, 2005; Forrester et al., 2006). The tolerance of eucalyptus to soil acidity and high $\mathrm{Al}$ contents, its adaptability to low soil fertility, and the ability to absorb N from different sources (Neves et al., 1990; Grespan et al., 1998) suggest that the use of this species in mixed plantations with $\mathrm{N}_{2}$-fixing leguminous trees could improve soil fertility and contribute to a more sustainable land use. Recent studies showed that intercropping eucalyptus with tree legumes was not detrimental to timber yield and resulted in increased soil $\mathrm{N}$ availability for eucalyptus (Binkley et al., 1992; Balieiro et al., 2002; Forrester et al., 2006). These results suggest that the implementation of such mixed forests may result in significant economical and ecological advantages due to the $\mathrm{N}$ input through biological nitrogen fixation (Forrester et al., 2006).

Another benefit of intercropping eucalyptus with leguminous trees is a potential increase in soil organic matter (SOM). Since eucalyptus litter degrades very slowly, it seems to contribute little to SOM replenishment (Resh et al., 2002). However, the lower $\mathrm{C} / \mathrm{N}$ ratio of the legume combined with eucalyptus litter results in a material with a higher turnover rate that could influence eucalyptus production (Balieiro et al., 2004; Forrester et al., 2006) and SOM contents (Resh et al., 2002; Resende et al., 2006) positively.

The use of stable isotopes of $\mathrm{C}$ in agricultural and ecological research has become more frequent (Vitorello et al., 1989; Neill et al., 1997; Gehring \& Vlek, 2004). The photosynthetic process in plants discriminates the $13 \mathrm{C}$ isotope against the lower atomic weight $12 \mathrm{C}$ at the carboxylation step. This discrimination is higher in C3 (Calvin cycle) than in C4 (Hatch-Slack cycle) plants, which brings about a 13C isotopic signature for each material that is relatively well preserved after decomposition in soil. Based on these differences, the analysis of the 13C natural abundance of SOM can be used to simply identify the $\mathrm{C}$ source to this C-pool or to investigate the SOM dynamics based on $13 \mathrm{C}$ natural abundance changes when a vegetation of long standing was replaced by another with a different $13 \mathrm{C}$ composition (Balesdent et al., 1988; Neill et al., 1997).

This study aimed to estimate: (a) the $\mathrm{C}$ and $\mathrm{N}$ stocks of a Planosol cultivated with a consortium of Eucalyptus grandis W. Hill ex Maiden and Pseudosamanea guachapele Kunth (Harms), a $\mathrm{N}_{2}$ fixing leguminous tree species, and (b) the contribution of residues of a tree species $\left(\mathrm{C}_{3}\right)$ to soil $\mathrm{C}$ in a longterm pasture based on the ${ }^{13} \mathrm{C}$ natural abundance. 


\section{MATERIAL AND METHODS}

\section{Site location and description}

The study site is located in an experimental field of Embrapa Agrobiologia (Brazilian Agricultural Research Company), in Seropédica, State of Rio de Janeiro $\left(22^{\circ} 46^{\prime} \mathrm{S}, 43^{\circ} 41^{\prime} \mathrm{W}, 33 \mathrm{~m}\right.$ asl). Mean annual rainfall at this site is $1.250 \mathrm{~mm}$, the air temperature between 16 and $32^{\circ} \mathrm{C}$ and average relative air humidity $73 \%$. The site topography consists of plain to slightly hilly and was used in the past for fertilized maize and bean cropping but in at least the last ten years before tree planting the area was occupied by Panicum maximum Jacq pasture, without any fertilization.

The soil is part of the Planosol Ecology Series, according to the Brazilian soil classification (Abruptic Arenic Ochraquult, according to Keys to Soil Survey Staff, 2006) (Ramos et al., 1973). This soil is characterized by a $1.0 \mathrm{~m}$ sandy topsoil ( $90 \%$ sand), low CEC, and low soil organic matter and nutrient contents. In a soil sampling prior to the experiment (1993) of the $0-20 \mathrm{~cm}$ layer the soil $\mathrm{pH}$ was 5.3 , the $\mathrm{Al}^{3+}$ content $0.2 \mathrm{cmol}_{\mathrm{c}} \mathrm{dm}^{-3}$, exchangeable $\mathrm{Ca}^{2+}+\mathrm{Mg}^{2+}$ $1.3 \mathrm{cmol}_{\mathrm{c}} \mathrm{dm}^{-3}$, and available $\mathrm{P}$ and $\mathrm{K} 10.3$ and $21 \mathrm{mg} \mathrm{dm}^{-3}$, respectively (Embrapa, 1979).

Pure and mixed plantations of eucalyptus (Eucalypus grandis) and guachapele (Pseudosamanea guachapele), a leguminous tree species native to Central America and Mexico, were established in 1993. Guachapele seeds were inoculated with selected Rhizobium strains (BR6205 and BR6821), provided by Embrapa Agrobiologia. The leguminous seeds were soaked in concentrated acid for ten minutes and washed thoroughly to remove any acid residue for homogeneous germination. Then, the moist seeds were inoculated with peat containing specific rhizobial strains (De-Polli \& Franco, 1985) and sowed directly in polystyrene recipients. Both species were inoculated with spores and hyphae of the mycorrhizal fungi Glomus clarum and Gigaspora margarita by covering seeds with $10 \mathrm{~g}$ of soil containing the inocula.

Each stand covered an area of $2,500 \mathrm{~m}^{2}$, with plants spaced $3 \mathrm{~m}$ between rows and $1 \mathrm{~m}$ within rows. The mixed plantation was implemented by intercropping rows of guachapele with eucalyptus. At transplanting, $100 \mathrm{~g}$ of rock phosphate $+10 \mathrm{~g}$ of fritted trace elements $(\mathrm{B}=1.8 ; \mathrm{Cu}=0.8 ; \mathrm{Fe}=3.0 ; \mathrm{Mn}=3.0 ; \mathrm{Mo}=0.1$ and $\mathrm{Zn}=9.0 \%)$ were added at the planting hole. Immediately after transplanting, $25 \mathrm{~g}$ ammonium sulfate per meter was also applied to eucalyptus seedlings at the soil surface, at a adistance of $0.5 \mathrm{~m}$ from the planting rows. No additional fertilizers were applied until soil sampling for analysis.

\section{Sampling and analytical methods}

Soil samples were collected in 1998 when the trees were five years old, and from an adjacent pasture of
Panicum maximum Jacq. The $P$. maximum pasture was ploughed annually to prevent fire in the experimental area during the dry season. Fifteen trenches were opened and soil samples were collected from the layers $0-2.5 ; 2.5-5.0 ; 5.0-7.5 ; 7.5-10 ; 10-$ 20 and $20-40 \mathrm{~cm}$. Air-dried soil samples (five composed samples for each area) were stored and ground later. All samples were analyzed for total C by loss-on-ignition, and for natural abundance ${ }^{13} \mathrm{C}$ using a Finnigan Delta Plus continuous-flow isotoperatio mass spectrometer interfaced with a Carlo Erba (Model EA 1108) automatic C-N analyzer (FinniganMAT, Bremen, Germany). The ${ }^{13} \mathrm{C}$ abundance in soil samples was expressed as $\delta^{13} \mathrm{C}$, which is a measure that refers to a standard expressed in parts per thousand:

$$
\delta^{13} \mathrm{C}(\%)=\frac{\left({ }^{13} \mathrm{C} / 12 \mathrm{C} \text { sample }-{ }^{13} \mathrm{C} /{ }^{12} \mathrm{C} \text { standard }\right)}{\left({ }^{13} \mathrm{C} /{ }^{12} \mathrm{C} \text { standard }\right)} \times 1.000
$$

The international standard is V-PDB (Vienna-Pee Dee Belemite). Delta ${ }^{13} \mathrm{C}$ values for higher plant species vary from -22 to $-33 \%$ in $\mathrm{C}_{3}$ plants to -9 to $16 \%$ in $\mathrm{C}_{4}$ plants (Deines, 1980).

\section{Estimation of $\mathrm{C}$ and $\mathrm{N}$ stocks and of $\mathrm{C}$ derived from trees}

Soil C and N stocks for pure and mixed tree stands and pasture were calculated based on soil C and N concentrations and soil bulk density, the latter estimated from undisturbed soil samples collected from each soil layer using a $100 \mathrm{~cm}^{3}$ steal cylinder. Soil bulk densities were then compared to calculate soil C and $\mathrm{N}$ stocks.

Soil texture was characterized in sub-samples collected from each soil layer by particle size class separation, using the pipet method described by Embrapa (1997).

SOM derived from tree residues (Cdft) in the top soil layer $(0-10 \mathrm{~cm})$ was expressed as percentage of total soil C (Vitorello et al., 1989). The \% of C derived from the tree species in a grass + tree stand was estimated using the following formula:

$$
\mathrm{Cdft}(\%)=\frac{\begin{array}{c}
\left(\delta^{13} \mathrm{C} \text { from the association }-\delta^{13} \mathrm{C}\right. \\
\text { of soil from grass alone })
\end{array}}{\begin{array}{c}
\left(\delta^{13} \mathrm{C} \text { of the tree residues }-\delta^{13} \mathrm{C}\right. \\
\text { of grass residues })
\end{array}} \times 100
$$

A Student's t-test was used to compare C and N contents and stocks between treatments (mixed crop vs. pasture; mixed crop vs. guachapele; mixed crop vs. eucalyptus; eucalyptus vs. guachapele; eucalyptus vs. pasture, and guachele vs. pasture). 


\section{RESULTS AND DISCUSSION}

\section{$\mathrm{C}$ and $\mathrm{N}$ stocks}

Soil texture and bulk density was quite uniform in the whole studied area (Table 1). The homogenity of soil bulk density in tree stands and pasture areas indicated no need for a correction of soil compaction in the calculation of soil $\mathrm{C}$ and $\mathrm{N}$ stocks, because no compaction had been induced, neither in the tree stand nor the pasture.

The sandy texture might have affected the $\mathrm{C}$ accumulation and stabilization in the soil of this study where, apart from the existing vegetation, the $\mathrm{C}$ contents were low when compared to soils under mixed indigenous tree plantations, native forest areas (GamaRodrigues et al., 1999; Resende et al., 2006), or Atlantic and Amazon forests (Neill et al., 1997; Tarré et al., 2001). The SOM in sandy well-aerated soils is poorly protected and more susceptible to microbial decomposition and mineralization (Franzluebbers et al., 1996).
The highest $\mathrm{C}$ content and stocks were observed in the topsoil $(0-20 \mathrm{~cm}$ ) for all treatments (Table 2). This fact could be related to the higher litter input under the trees (more than $10 \mathrm{Mg} \mathrm{ha}^{-1}$ year ${ }^{-1}$, Balieiro et al., 2004) and to the vigorous root system (Trujillo et al, 2006) and grass litter production (Rezende et al, 1999). The $\mathrm{C}$ contents in both pasture $\left(24.0 \mathrm{Mg} \mathrm{ha}^{-1}\right)$ and mixed stand (23.6 Mg ha-1) were higher than under pure stands of eucalyptus and guachapele (Figure 1).

Carbon stocks were higher $(p \leq 0.05)$ under the mixed than under pure plantations in the top soil layers $(0-7.5 \mathrm{~cm})$ (Figure 1$)$. The $\mathrm{C}$ content in the 10-20 cm layer was lower in the guachapele than in the mixed stand. The pasture site did not show significant differences down to the deepest sampled soil layer when compared to the soil under the mixed stand, although in the $10-20$ and $20-40 \mathrm{~cm}$ soil layers the $\mathrm{C}$ contents tended to be higher under pasture (Figure 1).

Differences in C stocks among tree stands and pasture were probably related to the litter quality of each system. Despite the fact that $\mathrm{C}$ accumulation

Table 1. Clay, fine and coarse sand and silt contents and bulk density of Planosol in different soil layers

\begin{tabular}{|c|c|c|c|c|c|}
\hline \multirow{2}{*}{ Soil layer } & \multicolumn{4}{|c|}{ Particles size } & \multirow{2}{*}{ Bulk density } \\
\hline & Clay & Fine sand & Coarse sand & Silt & \\
\hline $\mathrm{m}$ & 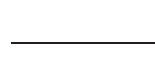 & 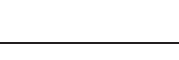 & & - & $\mathrm{Mg} \mathrm{m}^{-3}$ \\
\hline $0.0-2.5$ & $60 \pm 30^{(1)}$ & $220^{(2)}$ & $700 \pm 10$ & 30 & 1.37 \\
\hline $2.5-5.0$ & $60 \pm 30$ & 210 & $700 \pm 10$ & 30 & 1.37 \\
\hline $5.0-7.5$ & $60 \pm 20$ & 200 & $720 \pm 00$ & 20 & 1.37 \\
\hline $7.5-10.0$ & $70 \pm 20$ & 220 & $700 \pm 10$ & 20 & 1.41 \\
\hline $10.0-20.0$ & $70 \pm 30$ & 220 & $700 \pm 00$ & 30 & 1.41 \\
\hline $20.0-40.0$ & $70 \pm 30$ & 230 & $670 \pm 00$ & 30 & 1.47 \\
\hline
\end{tabular}

(1) Average values $(n=3)$. For each layer, samples from all treatments were not significantly different by $t$-test $(p<0.05)$.

${ }^{(2)}$ Average values and standard error equal to zero.

Table 2. Total carbon concentration \pm standard error for each soil layer and treatment

\begin{tabular}{ccccc}
\hline Layer & Pasture & Guachapele & Eucalyptus & Mixed \\
\hline $\mathrm{cm}$ & & & & \\
\cline { 2 - 4 } & & & & \\
$0.0-2.5$ & $5.97 \pm 0.03^{(1)}$ & $3.83 \pm 0.02$ & $5.17 \pm 0.03$ & $8.93 \pm 0.07$ \\
$2.5-5.0$ & $5.00 \pm 0.06$ & $3.67 \pm 0.02$ & $5.13 \pm 0.02$ & $7.30 \pm 0.01$ \\
$5.0-7.5$ & $6.50 \pm 0.04$ & $3.60 \pm 0.02$ & $4.13 \pm 0.01$ & $5.87 \pm 0.03$ \\
$7.5-10.0$ & $5.77 \pm 0.03$ & $3.13 \pm 0.01$ & $3.83 \pm 0.03$ & $4.57 \pm 0.02$ \\
$10.0-20.0$ & $5.17 \pm 0.02$ & $2.30 \pm 0.01$ & $3.30 \pm 0.01$ & $4.30 \pm 0.02$ \\
$20.0-40.0$ & $2.97 \pm 0.00$ & $2.10 \pm 0.01$ & $2.20 \pm 0.01$ & $2.87 \pm 0.02$ \\
\hline
\end{tabular}

(1) Data are means of five replications. 
may be related to $\mathrm{N}$ inputs to the soil (Evangelou \& Blevins, 1984; Resh et al., 2002; Sisti et al., 2004), no significant increase in soil $\mathrm{C}$ and $\mathrm{N}$ stocks were detected in the pure guachapele stand, where the $\mathrm{N}$ input reached over $250 \mathrm{~kg} \mathrm{ha}^{-1}$ (Balieiro et al., 2004). The low $\mathrm{C} / \mathrm{N}$ ratio and the relative low lignin and polyphenol contents of the guachapele residues indicate a high decomposition potential (Balieiro, 2002) that could result in higher SOM decomposition rates.

Soil N concentrations performed similarly as soil $\mathrm{C}$ in relation to soil depth (Table 3 ) confirming the close relationship with SOM. Again, the highest soil $\mathrm{N}$ contents were observed in the mixed plantation and pasture.

Soil N stocks followed the same trend of C, although significant differences $(\mathrm{p}<0.05)$ were detected among pure and mixed plantations (Figure 2).

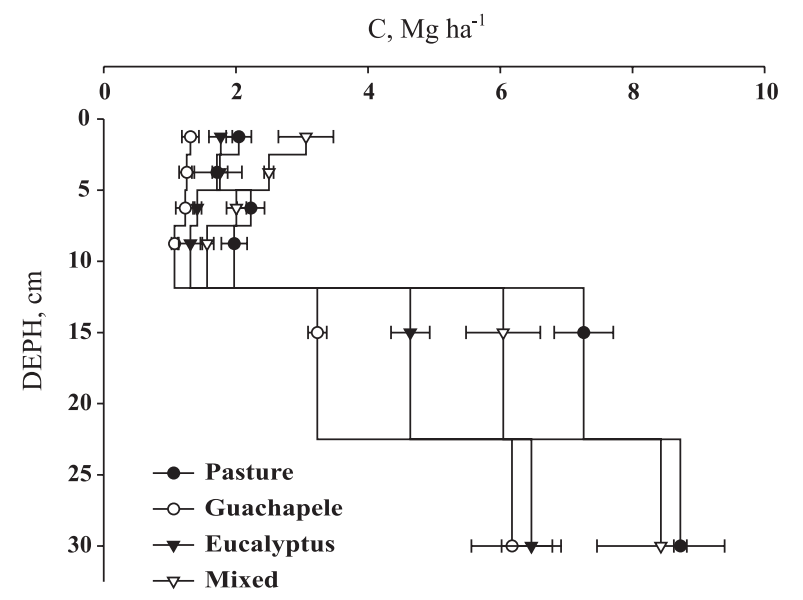

Figure 1. Estimates of $\mathrm{C}$ stocks in different soil layers (0-2.5, 2.5-5.0, 5.0-7.5, 7.5-10.0, 10-20 and 20$40 \mathrm{~cm}$ ) under pasture and pure and mixed plantations of Eucalyptus grandis and Pseudosamanea guachapele. Bars indicate standard errors of means.
Further investigation on existing mechanisms to protect soil organic matter from mineralization (recalcitrance, occlusion and complexion) is needed to model $\mathrm{C}$ sequestration, particularly when the chemical composition of plant residues differs. Despite the best litter quality, the $\mathrm{N}$ stock was lowest in the guachapele stand. The higher nitrification and denitrification rates in this stand could increase the $\mathrm{N}$ loss when high $\mathrm{N}$ quantities were introduced and the soil moisture content tended to be higher in this stand than in the other systems (Balieiro, 2002).

\section{$\delta^{13} \mathrm{C}$ in soil and carbon derived from trees and pasture}

Delta ${ }^{13} \mathrm{C}$ values of SOM (Figure 3 ) increased with depth in the top soil layers as a function of the change in the $\delta^{13} \mathrm{C}$ of the source material, and mainly, as a result of a preferential decomposition and removal of

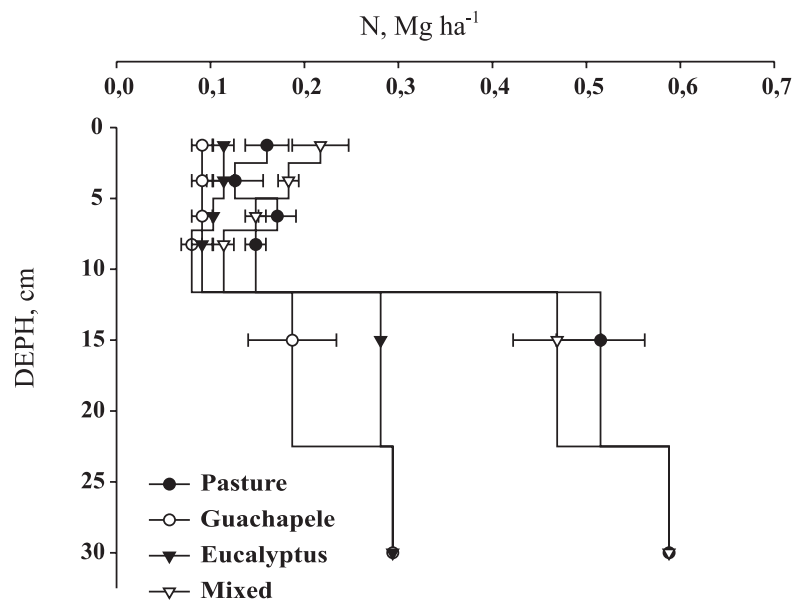

Figure 2. Estimates of $\mathrm{N}$ stocks in different soil layers (0-2.5, 2.5-5.0, 5.0-7.5, 7.5-10.0, 10-20 and 20$40 \mathrm{~cm}$ ) under pasture, pure and mixed plantations of Eucalyptus grandis and Pseudosamanea guachapele. Bars indicate standard errors of means.

Table 3. Soil $N$ concentration \pm standard error of different layers and treatments. Data are means of three replications

\begin{tabular}{|c|c|c|c|c|}
\hline Layer & Pasture & Guachapele & Eucalyptus & Mixed \\
\hline $\mathrm{cm}$ & & 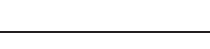 & & \\
\hline $0.0-2.5$ & $0.47 \pm 0.00^{\#}$ & $0.27 \pm 0.00$ & $0.33 \pm 0.00$ & $0.63 \pm 0.01$ \\
\hline $2.5-5.0$ & $0.37 \pm 0.01$ & $0.27 \pm 0.00$ & $0.33 \pm 0.00$ & $0.53 \pm 0.00$ \\
\hline $5.0-7.5$ & $0.50 \pm 0.00$ & $0.27 \pm 0.00$ & $0.30 \pm 0.00$ & $0.43 \pm 0.00$ \\
\hline $7.5-10.0$ & $0.43 \pm 0.00$ & $0.23 \pm 0.00$ & $0.27 \pm 0.00$ & $0.33 \pm 0.00$ \\
\hline $10.0-20.0$ & $0.37 \pm 0.00$ & $0.13 \pm 0.00$ & $0.20 \pm 0.00$ & $0.33 \pm 0.00$ \\
\hline $20.0-40.0$ & $0.20 \pm 0.00$ & $0.10 \pm 0.00$ & $0.10 \pm 0.00$ & $0.20 \pm 0.00$ \\
\hline
\end{tabular}

\footnotetext{
(1) Means of five replications.
} 


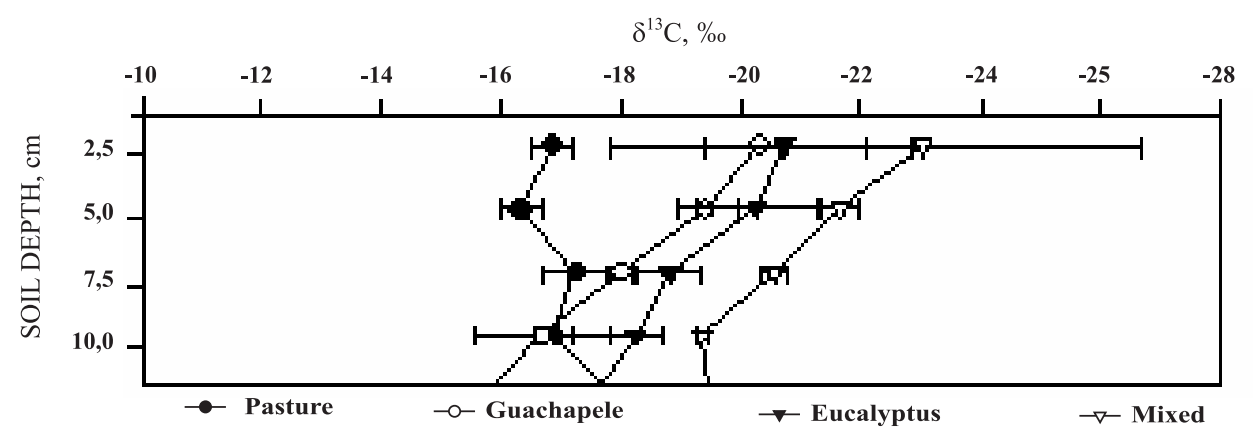

Figure 3. Distribution of natural abundance ${ }^{13} \mathrm{C}$ in relation to soil depth in different systems. Bars indicate standard errors of the means.

${ }^{13} \mathrm{C}$-impoverished components or molecules (Natelhoffer \& FRY, 1988; Vitorrelo et al., 1989; Rao et al., 1994).

Significant differences in $13 \mathrm{C}$ values were observed between samples from pasture and mixed plantations indicating a preferential $\mathrm{C}$ stabilization from $\mathrm{C} 3$ origin. After five years, up to $60 \%$ of the soil organic $\mathrm{C}$ in the mixed plantation was estimated to be derived from the trees in the $0-2.5 \mathrm{~cm}$ layer, and this participation decreased to about $24 \%$ in the 7.5 $10.0 \mathrm{~cm}$ layer (Figure 4). Under pure guachapele plantation the percentage decreased to $0 \%$ in the 7.5 $10.0 \mathrm{~cm}$ layer, while this value reached $37 \%$ in the upper layer (Figure 4). It is possible that a higher $\mathrm{N}$ input and decomposition rate of leaf litter of guachapele species (Balieiro et al., 2004) stimulated the mineralization of recent fixed $\mathrm{C}$ or, also, the $\mathrm{C}$ deposition to this depth derived from guachapele was negligible. Despite the low Pannicum presence in the understory of the pure eucalyptus and guachapele plantations, the grass may have contributed to the higher proportion of grass C (Figure 4).

The effect of $\mathrm{N}$ addition on decomposition may vary with the substrate composition. Hobbie (2000), cited by Resh et al. (2002), found that $\mathrm{N}$ addition increased decomposition of leaves with a low but not with a high lignin content. The combination of residues with different chemical quality in the mixed stand could stabilize recent soil C, mainly because in this system $\mathrm{N}$ could be added via biological $\mathrm{N}_{2}$ fixation. Resh et al. (2002) compared the soil $\mathrm{C}$ pools under $\mathrm{N}_{2}$ fixing trees with Eucalyptus species in Hawaii and Puerto Rico using stable $\mathrm{C}$ isotope technique and concluded that $55 \%$ of the soil organic $\mathrm{C}$ sequestration under $\mathrm{N}_{2}$ fixation resulted from a greater retention of old soil organic carbon (SOC) from $\mathrm{C}_{4}$ species and $45 \%$ resulted from new $\mathrm{SOC}$ derived from $\mathrm{C}_{3}$.

\section{CONCLUSIONS}

1. Mixed plantations of Eucalyptus grandis and Pseudosamanea guachapele favor the conservation of soil $\mathrm{C}$ and $\mathrm{N}$ stocks and

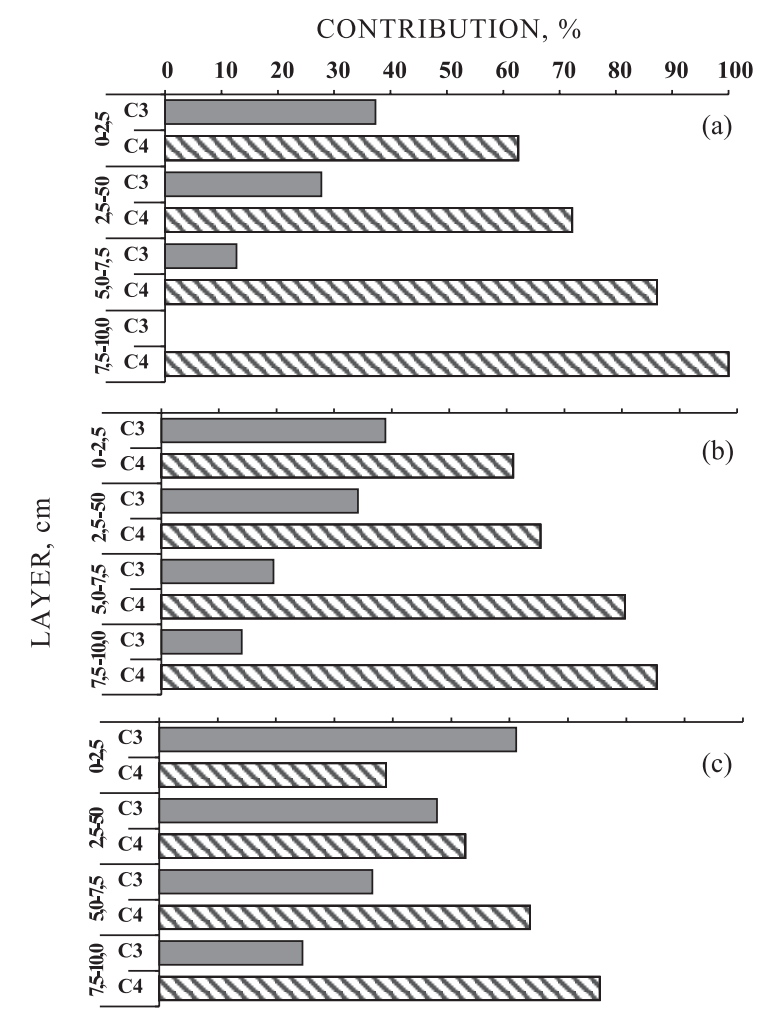

Figure 4. Relative contribution of $\mathrm{C}$ derived from pasture $\left(C_{4}\right)$ and from trees $\left(C_{3}\right)$ in the $0-10 \mathrm{~cm}$ soil layer under guachapele (a), eucalyptus (b) and mixed plantations (c).

2. Up to $40 \%$ of the soil organic $\mathrm{C}$ in a mixed plantation was estimated to be derived from trees, while in pure eucalyptus and guachapele plantations these same estimates were only 19 and $27 \%$, respectively.

\section{LITERATURE CITED}

BALESDENT, J.; WAGNER, G.H. \& MARIOTTI, A. Soil organic matter in long-term experiments as revealed by carbon-13 natural abundance. Soil Sci. Soc. Am. J., 52:118124,1988 
BALIEIRO, F.C. Dinâmica de nutrientes e da água em plantios puro e mistos de Pseudosamanea guachapele Harm (Kunth) e Eucalyptus grandis W. Hill ex Maiden, Seropédica, RJ. Seropédica, Universidade Federal Rural do Rio de Janeiro, 2002. 99p. (Tese de Doutorado)

BALIEIRO, F.C.; FRANCO, A.A.; FONTES, R.L.F.; DIAS, L.E.; CAMPELLO, E.F. \& FARIA, S.M. Accumulation and distribution of aboveground biomass and nutrients under pure and mixed stands of Pseudosamanea guachapele Dugand e Eucalyptus grandis W. Hill ex Maiden. J. Plant Nutr., 24/25:2639-2654, 2002.

BALIEIRO, F.C.; FRANCO, A.A.; CAMPELO, E.F.C.; DIAS, L.E.; PEREIRA, M.G.; FARIA, S.M. \& ALVES, B.J.R. Deposição de serapilheira e nitrogênio em plantios de guachapele e eucalipto aos sete anos de idade. Pesq. Agropec. Bras., 39:597-601, 2004.

BINKLEY, D.; DUNKIN, K.A.; DEBELL, D.S. \& RYAN, M.G. Production and nutrient cycling in mixed plantation of Eucalyptus and Albizia in Hawaii. For. Sci., 38:393-408, 1992.

DEINES, P. The isotopic composition of reduced organic carbon. In: FRITZ, P. \& FONTES, J.C., eds. Handbook of environmental isotopes geochemistry. Amsterdam, Elsevier, 1980. v.1, 329-406.

DE-POLLI, H. \& FRANCO, A.A. Inoculação de sementes de leguminosas. Seropédica, Embrapa - UAPNPBS, 1985. 31p. (Circular Técnica, 1)

EMPRESA BRASILEIRA DE PESQUISA AGROPECUÁRIA . EMBRAPA. Centro Nacional de Pesquisa em Solos. Manual de métodos de análise de solo. Rio de Janeiro, 1997. 212p.

EVANGELOU, V. \& BLEVINS, R.L. Soil-solutions phase interactions of basic cations in long-term tillage systems. Soil Sci. Soc. Am. J., 49:357-362, 1984.

FORRESTER, D.; BAUHUS, J.; COWIE, A.L. \& VANCLAY, J.K. Mixed-species plantations of Eucalyptus with nitrogen fixing trees: A review. For. Ecol. Manag., 233:211-230, 2006 .

FRANZLUEBBERS, A.J.; HANEY, R.L.; HONS, F.M. \& ZUBERER, D.A. Active fractions of organic matter in soils with different texture. Soil Biol. Biochem., 28:13671372,1996

GAMA-RODRIGUES, A.; BARROS, N.F. \& MENDONÇA, E.S. Alterações edáficas sob plantios puros e mistos de espécies florestais nativas do sudeste da Bahia. R. Bras. Ci. Solo, 23:581-592, 1999.

GEHRING, C. \& VLEK, P.L.G. Limitations of the ${ }^{15} \mathrm{~N}$ natural abundance method for estimating biological nitrogen fixation in Amazonian forest legumes. Basic Appl. Ecol., 5:567-580, 2004 .

GRESPAN, S.L.; DIAS, L.E. \& NOVAIS, R.F. Crescimento e parâmetros cinéticos de absorção de amônio e nitrato por mudas de Eucalyptus spp., submetidas a diferentes relações amônio/nitrato na presença e ausência de fósforo. R. Bras. Ci. Solo, 22:667-674, 1998.
NATELHOFFER, K.J. \& FRY, B. Controls on natural nitrogen15 and carbon-13 abundance in forest soil organic matter. Soil Sci. Soc. Am. J., 52:1633-1640, 1988.

NEILL, C.; MELILLO, J.M.; STEUDLER, P.A.; CERRI, C.; MORAES, F.L.; PICCOLO, F.C. \& BRITO, M. Soil carbon and nitrogen stocks following forest clearing for pasture in the southwestern Brazilian Amazon. Ecol. Appl., 7:1216. $1225,1997$.

NEVES, J.C.L.; GOMES, J.M. \& NOVAIS, R.F. Fertilização mineral de mudas de eucalipto. In: NOVAIS, R.F. \& BARROS, N.F., eds. Relação solo-eucalipto. Viçosa, MG, Folha de Viçosa, 1990. p.99-126.

NOVAIS, R.F. \& BARROS, N.F. Sustainable agriculture and forest production systems on acid soils: Phosphorus as a case-study. In: MONIZ, A.C.; FURLANI, A.M.C.; SHAFFERT, R.E.; FAGERIA, N.K.; ROSOLEM, C.A. \& CANTARELLA, H., eds. Plant and soil interaction at low pH. Campinas, Brazilian Soil Science Society, 1997. p.39-51.

PASCHOAL, E. Novos rumos para o país. JB Ecológico, 39:18$27,2005$.

RAMOS, D.P.; CASTRO, A.F. \& CAMARGO, M.N. Levantamento detalhado de solos da área da Universidade Federal Rural do Rio de Janeiro. Pesq. Agropec. Bras., 8:1-27, 1973. (Série Agronomia)

RAO, I.M.; AYARZA, M.A. \& THOMAS, R.J. The use of carbon isotope ratio to evaluate legume contribution to soil enhancement in tropical pastures. Plant Soil, 162:177182,1994

RESENDE, A.S.; MACEDO, M.; CAMPELLO, E.F.C. \& FRANCO, A.A. Recuperação de áreas degradadas através da reengenharia ecológica. In: GARAY, I. \& BECKER, B.K., orgs. Dimensões humanas da biodiversidade: O desafio de novas relações sociedade-natureza no século XXI. Petrópolis, Vozes, 2006. p.315-340.

RESH, S.C.; BINKLEY, D. \& PARROTA, J.A. Greater soil carbon sequestration under nitrogen-fixing trees compared with Eucalyptus species. Ecosystems, 5:217231,2002

REZENDE, C.P.; CANTARUTTI, R.B.; BRAGA, J.M.; GOMIDE, J.A.; PEREIRA, J.M.; FERREIRA, E.; TARRÉ, R.; MACEDO, R.; ALVES, B.J.R.; URQUIAGA, S.; CADISCH, G.; GILLER, K.E. \& BODDEY, R.M. Litter deposition and disappearance in Brachiaria pastures in Atlantic forest region of South of Bahia, Brazil. Nutr. Cycling Agroecosyst., 54:99-112, 1999.

SISTI, C.P.J.; SANTOS, H.P.; KOHHANN, R.; ALVES, B.J.R.; URQUIAGA, S. \& BODDEY, R.M. Change in carbon and nitrogen stocks in soil under 13 years of conventional or zero tillage in Southern Brazil. Soil Till. Res., 76:39-58, 2004.

SOIL SURVEY STAFF. Keys to soil taxonomy. 10.ed. Washington, USDA-SCS, 2006. 332p.

TARRÉ, R.; MACEDO, R.; CANTARUTTI, R.B.; REZENDE, C.P.; PEREIRA, J.M.; FERREIRA, E.; ALVES, B.J.R.; URQUIAGA, S. \& BODDEY, R.M. The effects of the presence of a forage leguminous on nitrogen and carbon levels in soils under brachiaria pasture in the Atlantic Forest region of the South of Bahia, Brazil. Plant Soil, 234:15-26, 2001. 
TRUJILLO, W.; FISHER, M.J. \& LAL, R. Root dynamics of native savannah and introduced pastures in the Eastern Plains of Colombia. Soil Till. Res., 87:28-38, 2006.
VITORELO, V.A.; CERRI, C.C.; ANDREUX, F.; FELLER, C. \& VICTÓRIA, R.L. Organic matter and natural carbon-13 distribution in forest and cultivated oxisols. Soil Sci. Soc. Am. J., 53:773-778, 1989. 